\title{
Weodzimierz Pawluczuk
}

UNIWERSYTET W BIAŁYMSTOKU

E-MAIL:WLODEKPAW@GMAIL.COM

\section{POWIKŁANE LOSY UKRAINY}

\section{Substrat plemienny}

Ukraina, podobnie jak Białoruś, leży w obszarze szeroko pojętej łacińsko-bizantyjskiej rubieży cywilizacyjnej. Miało to swój oczywisty wpływ na kształtowanie się świadomości narodowej na całym tym obszarze, jak też na jej stan w dniu dzisiejszym. W obu krajach w ideologicznych zmaganiach ważne miejsce zajmuje to, co w Polsce nazywane jest "polityką historyczną" - świadome, ideologiczne kreowanie własnej historii. Wśród wielu pytań, które tu są stawiane, ważne jest pytanie o etnogenezę narodu.

Wielu badaczy wskazuje jednak na znaczenie pierwotnego substratu plemiennego, który na ziemiach wschodniosłowiańskich istniał przed przybyciem tu Słowian i prawdopodobnie stopniowo wsiąknął w żywioł słowiański. W przypadku Białorusinów tym substratem były zamieszkujące pierwotnie terytorium dzisiejszej Białorusi plemiona Bałtów, w przypadku Rosji - plemiona ugro-finów [Jermałowicz 1990]. Mniej pewne choć też prawdopodobne są wpływy irańskie na etnos Ukrainy. Tereny dzisiejszej Ukrainy w pierwszych stuleciach naszej ery zamieszkiwali bowiem Scytowie, zaliczani do grupy ludów indoirańskich. Na przełomie tysiącleci panowali tu Sarmaci i Goci. W IV i V stuleciach tereny te zajęli przybyli z Azji Centralnej Hunowie, a następnie Bułgarzy. Bezpośrednio przed przybyciem Słowian obszar ten zamieszkały był prawdopodobnie przez germańskie plemiona Rusów. Lew Gumilow przestrzega, by nie mylić Rusów z Waregami, ci ostatni bowiem dokonują swoich wypraw na ziemie „ruskie” dopiero w IX wieku. Rusowie zaś znani są historykom już w VI wieku [Gumilow 1997].

Treny późniejszej Rusi zostały dopiero w VIII wieku zdobyte przez Słowian przybyłych prawdopodobnie z górnego dorzecza Wisły, czyli z terenów południowej Polski. 
Elitą polityczną tego państwa są początkowo Waregowie. Pierwsza wzmianka o Rusi (Ros) pochodzi z roku 839, a jej autorem był arabski kronikarz Ibn-Churdadhbeh - dotyczy ona władztwa właśnie Waregów. Waregowie szybko jednak slawianizują się. Początkowo ich głównym ośrodkiem była Ładoga Wielka nad jeziorem Ładoga, a później - Nowogród Wielki.

Normańskie (wareskie) pochodzenie państwowości ruskiej bogato dokumentuje w swym dziele poświęconym tej tematyce Henryk Paszkiewicz [1995]. Obecności czynnika normańskiego w powstaniu państwowości ruskiej nikt nie zaprzecza, autorzy rosyjscy, zwłaszcza piszący w czasach radzieckich, podnosili jednak tezę, iż przed wkroczeniem na ten teren Waregów istniały już tu plemienne związki o charakterze państwowym i Waregowie nie odegrali roli decydującej w kształtowaniu się państwowości ruskiej.

Zdaniem H. Paszkiewicza, głównym czynnikiem slawizacji różnych plemion, z którymi Słowianie zetknęli się na tych terenach, był fakt posiadania przez nich własnego piśmiennictwa, stworzonego w IX wieku przez Cyryla i Metodego. Autor pisze: „Nie należy zapominać, że zanim normańscy Waregowie osiedlili się ostatecznie w Kijowie (połowa X wieku), obrządek Cyryla i Metodego utrwalił się wśród Polan. Pozostanie wiekopomną zasługą obu misjonarzy, że z mowy Słowian uczynili język pisany, przystosowany przede wszystkim, ale nie wyłącznie do potrzeb liturgicznych. Rozwój chrześcijaństwa na wschodzie oznaczał równocześnie rozwój języka słowiańskiego. Ten fakt dał Słowianom kapitalną przewagę nad najeźdźcami - Waregami i Litwinami [Paszkiewicz 1996: 302] ${ }^{1}$.

Charakter narodowy dawnej Rusi jest ciągle przedmiotem sporu. Historycy rosyjscy traktują Rosję moskiewską jako prostą kontynuację tradycji narodowej i politycznej dawnej Rusi. Ma to obecnie wyraźną wymowę ideologiczną, niebezpieczną w swych konsekwencjach uwzględniwszy sytuację polityczną współczesnej Ukrainy. Rosyjscy politycy i ideolodzy nadal żywią pretensje do roli Rosji jako „naturalnego sukcesora” dawnej Rusi, której centralnym ogniwem była właśnie Ukraina. Ma to być swoiste moralne „usprawiedliwienie” specyficznie rozumianej „troski” Moskwy dzisiejszym politycznym charakterem Ukrainy.

Historycy ukraińscy i białoruscy skłonni są widzieć dawną Ruś jako swoistą federację "narodowych” organizmów państwowych: ukraińskich i białoruskich. Białorusini, jako pierwsze „niepodległe” państwo białoru-

4 W Wielkim Księstwie Litewskim językiem „urzędowym” był język staroruski. W tym języku sporządzano państwowe dokumenty; 90\% mieszkańców WKL stanowili „Rusini”. 
skie skłonni są traktować Księstwo Połockie, zajmujące północną część dzisiejszej Białorusi, z Mińskiem włącznie. Niezależni historycy, tacy jak cytowany tu H. Paszkiewicz, czy A. Wilson [2002], uważają jednak, iż rozbicie dzielnicowe Rusi Kijowskiej było zjawiskiem typowym dla Europy w tym okresie rozwoju społeczeństw feudalnych i miało charakter dynastyczny, a nie etniczny. Podobne poglądy wyrażają też niektórzy historycy białoruscy [zob. Zaharulski 1998]. Poszczególne księstwa dzieliły się i łączyły bez jakiegokolwiek względu na charakter etniczny zamieszkującej je ludności. Zawartość tekstów literackich z tego okresu, takich jak Słowo o pułku Igora, czy liczne kroniki, wskazują jednak wyraźnie, iż również w okresie rozbicia dzielnicowego Rusi Kijowskiej istniała wyraźna świadomość jedności politycznej, religijnej i kulturowej „ruskiej ziemi”. Tożsamość etniczna dzisiejszej Ukrainy w średniowieczu była związana z przyjęciem chrześcijaństwa w obrządku wschodnim. Geneza średniowiecznej państwowości ruskiej jest dość zagadkowa, ze względu na poświadczone w dokumentach historycznych normańskie (wareskie) pochodzenie pierwszej dynastii władców Rusi. Sporny jest udział Normanów, czy ściślej - Waregów w powstaniu i organizacji tej państwowości.

Henryk Paszkiewicz w swym studium początków Rusi śledzi ideologiczną konotację pojęcia „Ruś” na przestrzeni 250 lat od panowania Włodzimierza Wielkiego do najazdu Tatarów. Konstatuje on występowanie w tym czasie dwóch desygnatów tego pojęcia: geograficznego i religijnego. Po skrupulatnym prześledzeniu źródeł stwierdza: Kroniki z interesującego nas okresu pozwalają ustalić fakt niewątpliwy, że „Rusią” w znaczeniu geograficznym była ziemia kijowska (wraz z periasławską i czernihowską). Halicz i Wołyń, Smoleńsk i Połock, Murom i Riazań, Rostów, Suzdal i Włodzimierz nad Klaźmą, Wielki Nowogród ani siebie nie uważały, ani ich nie uważano za „Ruś” [Paszkiewicz 1996: 13].

Poza tym znaczeniem Ruś ma w omawianym okresie znaczenie religijne - oznacza wszystkich wyznawców Kościoła Wschodniego podległych metropolicie ruskiemu (kijowskiemu), [Paszkiewicz 1996: 14]. Byli to ludzie „ruskiej wiary.”

Z punktu widzenia historii „ruskiej idei,” szczególnie interesujące są konstatacje Paszkiewicza dotyczące zamiennie używanych trzech pojęć - „wiera”, „ziemla” i „jazyk”. Są to właściwie synonimy. Ludzie „ruskiej wiary”, "ruska ziemia” i „ruski język” oznaczają to samo: wyznawców „ruskiego” kościoła. Zwłaszcza interesujące jest tu znaczenie pojęcia jazyk. Autor ten przytacza obszerną dokumentację na poparcie tezy, iż określenie „ludzie języka ruskiego" w dokumentach ruskich z X-XIII wieku wcale nie ozna- 
czało ludzi mówiących językiem „ruskim”, czyli wschodniosłowiańskim. Oznaczało ono chrześcijan w obrządku Cyryla i Metodego. Ruskie określenie pogan jako jazyczniki brzmiało pierwotnie inojazyczniki - ludzie innego języka, czyli innej wiary. Oto jeden z dowodów przytoczony przez Paszkiewicza: „Opowiada Nestor (pod r. 983) jak to dwóch Waregów w Kijowie, ojciec z synem wolało życie poświęcić, niż zaprzeć się Chrystusa. Pateryk kijowski zachował wiadomość o męczeńskiej śmierci biskupa rostowskiego, Greka Leoncjusza (Leontego), który, przez ofiarę złożoną z własnego życia, stał się «trzecim obywatelem świata ruskiego» wraz z dwoma Waregami i został uwieńczony przez Chrystusa, ponieważ cierpiał dla niego. W opinii więc kościelnej Kijowa pierwszymi najgodniejszymi «Rusinami» byli dwaj Normanowie i jeden Grek!” [Paszkiewicz 1996: 30].

„Rusią, zdaniem Paszkiewicza, byli tu nie tylko Słowianie Wschodni, ale i Zachodni - Polacy (o ile byli wyznawcami „wiary ruskiej”), ale także Nie-Słowianie: Grecy, Waregowie, Litwini, Finowie z rejonu Wołgi i Oki, Połowcy [Paszkiewicz 1996: 29].

Paszkiewicz skrupulatnie przeanalizował pierwotną strukturę plemienną Rusi Kijowskiej. Plemiona Bużan, Wołynian i Dulebów, traktowanych całościowo jako Bużanie, zamieszkiwały dorzecze Bugu i dalej na wschód, aż po rzekę Styr na Ukrainie. Przynależeli oni w całości do kultury lechickiej, czyli, w dzisiejszych kategoriach - polskiej. W kronikach ruskich, zwłaszcza w kronice Nestora, są oni traktowani jako „Lachy”, przeciwko którym książęta kijowscy organizują zwycięskie wyprawy. Równolegle niejako są oni traktowani w tychże kronikach jako „Ruscy”. Te niekonsekwencje Paszkiewicz wyjaśnia współwystępowaniem kolejnych dwóch znaczeń pojęcia „Ruś” i „Ruski” - etnicznego i religijnego. Bużanie byli „z pochodzenia” Lechitami (Lachami), czyli według dzisiejszych naszych pojęć - Polakami, byli jednak „wiary ruskiej”, a więc w tym sensie „Ruskimi”. Sumując swe rozważania nad charakterem etnicznym pogranicza polsko-ruskiego w IX-XIII wieku Paszkiewicz pisze: „Jak należałoby nazwać późniejszą ludność znad Sanu, Dniestru i Bugu? Sądzę, że najwłaściwszy byłby termin, którego użył «Nestor», pisząc o Radymiczach: ot roda Lachow, tj. lackiego (polskiego) pochodzenia" [1996: 109].

Charakterystyczne, że te plemienne identyfikacje mają znaczenie polityczne jeszcze na początku IX wieku, pod koniec stulecia te podziały się zacierają na rzecz podziału cywilizacyjnego - na chrześcijaństwo zachodnie i chrześcijaństwo wschodnie. W następnych stuleciach znika nawet pamięć o pierwotnych identyfikacjach plemiennych, dominuje identyfikacja religijno-cywilizacyjna: podział na chrześcijan wiary „ruskiej” i „łacinników”. 
Ten podział, a nie podziały plemienne staje się wyznacznikiem ideologii państwa polskiego i państwa ruskiego. Ruś Kijowska rości sobie prawo panowania nad wszystkimi ludami „wiary ruskiej”.

Podział Lechitów na „ruskich” i „łacińskich”, a zatem - polskich w IX-XIII wieku wiąże się $\mathrm{z}$ ostrą walką między Rzymem i Bizancjum o sfery wpływów. Formalnie zerwanie jedności Kościoła Powszechnego nastąpiło w 1054 roku, jednak faktyczna walka o dominację w Europie tych dwóch ośrodków cywilizacyjnych ma długą historię. Rywalizacja ta, szczególnie ostrą formę, przyjmuje w IX wieku w Państwie Wielkomorawskim.

Historia - przy całym szacunku dla jej wysiłków naukowego obiektywizmu - jest szukaniem odpowiedzi na pytania, które stawia przed nami współczesność. W przypadku narodów wschodniosłowiańskich - Rosjan, Ukraińców, Białorusinów - jest to między innymi poszukiwanie źródeł własnej tożsamości. Przez historiografię tego obszaru prześlizgują się dwie tendencje - jedna $\mathrm{z}$ nich, związana $\mathrm{z}$ rosyjską ideologią panruskości, poszukuje historycznych uzasadnień wschodniosłowiańskiej (ruskiej) wspólnoty, druga - obecna zwłaszcza w historiografii ukraińskiej i białoruskiej, poszukuje tego, co Ukraińców i Białorusinów różni od Rosjan. Jest przy tym pokusa, by te różnice przenieść w czasy jak najbardziej zamierzchłe, w prehistorię, by udowodnić, że Ukraińcy zawsze byli Ukraińcami, a Białorusini - Białorusinami. Próby te przybierają często charakter świadomie tworzonych mitologii, jak na przykład w „historii Ukrainy” Lwa Sylenki, proroka ukraińskiej narodowej religii, Runwiry, gdzie Ukraińcy są u źródeł całej historii ludzkości, twórcami ludzkiej cywilizacji. Pomijając jednak te, raczej zabawne, skrajności, naturalna jest skłonność do szukania swego narodowego rodowodu $\mathrm{w}$ prehistorycznych strukturach plemiennych, w ten sposób własny naród nie jest kaprysem takich, czy innych zawirowań historycznych, ale czymś danym niejako ontycznie. Istnieje on sam z siebie sprzed wieków, niezależnie od tego, czy chcemy tego czy nie chcemy, a nawet - niezależnie od tego, czy jesteśmy tego świadomi czy nie.

Najbardziej bezstronną i solidną zarazem analizę procesu kształtowania się etnosu ukraińskiego przynosi książka Andrewsa Wilsona: Ukraińcy. Tytuł oryginału dzieła Wilsona brzmi: The Ukrainians. Unexpected Nation. (Ukraincy. Naród niespodziewany), [Wilson 2002]. Pisząc o Rusi Kijowskiej, autor ten stwierdza, iż uznać należy, że w tym czasie ukształtowała się jedność kulturowa tych ziem, zaczęła się też kształtować „elitarna kultura wyższa”. Autor podaje, iż w XI stuleciu na terytorium tym było ponoć w obiegu 140000 książek dla wszystkich zrozumiałych [Wilson 2002: 6]. Istniała zatem (w formie zaczątkowej) świadomość Rusi jako politycznej 
i etnicznej całości, świadomość zaś „dwóch Rusi”: kijowskiej i późniejszej moskiewskiej w ogóle nie istniała. „Spory wewnętrzne miały bardziej charakter konfliktów między poszczególnymi książętami niż waśni etnicznych [Wilson 2002: 19]. Do podobnego poglądu zdaje się skłaniać również wybitny ukraiński historyk Mychajło Hruszewskyj [1992].

Zróżnicowanie kulturowe i w jakimś sensie - również świadomościowe następuje znacznie później, po inwazji na ziemie ruskie Mongołów.

Szczytowym okresem w historii Rusi Kijowskiej było panowanie Włodzimierza Wielkiego (980-1015) i Jarosława Mądrego (1019-1054). W 988 roku Włodzimierz przyjął chrześcijaństwo w obrządku bizantyjskim. Założył w Kijowie biskupstwo i metropolię dla całej Rusi, podległą patriarsze konstantynopolskiemu. Zdobycze terytorialne i polityczne Włodzimierza utrwalił Jarosław Mądry. Głównym jego zwycięstwem było przede wszystkim pobicie Pieczyngów, zagrażających Rusi od południowego wschodu, a także zdobycze terytorialne na północnym zachodzie po podboju plemion ugrofińskich.

Panowanie Jarosława Mądrego kończy okres świetności Rusi i rozpoczyna okres rozdrobnienia feudalnego. Jarosław podzielił kraj między pięciu swych synów, co rozpoczęło okres wzajemnych walk książąt dzielnicowych, zerwanie związków gospodarczych z Bizancjum, upadek znaczenia Kijowa, jako ośrodka politycznego i cywilizacyjnego Rusi. Korzystały z tego osiadłe na czarnomorskich stepach plemiona Połowców i Pieczyngów dokonując łupieżczych najazdów na osłabione księstwa ruskie. W 1237 roku na teren rozdrobnionej i osłabionej Rusi najechali Mongołowie, pod wodzą Batuchana. W 1240 roku Mongołowie zdobyli i spustoszyli Kijów. Ziemie Rusi na prawie dwa stulecia znalazła się pod jarzmem mongolskim.

Tendencja do postępującego coraz głębszego rozdrobnienia udzielnych księstw, łączyła się z odrębną tendencją: próbą łączenia księstw i powrotu do jakiejś formy scentralizowanej władzy. Najbardziej udanym tego typu organizmem politycznym na ziemiach byłej Rusi Kijowskiej było Księstwo Halicko-Włodzimierskie, obejmujące zachodnie ziemie byłej Rusi Kijowskiej. Wybitą postacią polityczną był tu książę włodzimierski Daniło (1221-1264), który w roku 1234 przyłączył do swego księstwa ziemię halicką, a w roku 1253 za zgodą papieża Innocentego IV koronował się w Drohiczynie na króla. Przez cały okres swego panowania próbował organizować koalicję antytatarską, usiłował uzyskać w tym wsparcie również papieża, uznawszy jego zwierzchnictwo religijne na rządzonych przez siebie ziemiach ruskich. Gdy jednak okazało się, iż wsparcia takiego nie otrzymał, zerwał z Rzymem, prowadząc samotnie nierówną walkę ze Złotą Ordą. 
W tym czasie zaczynają kształtować się wyraźne różnice kulturowe i polityczne między wschodnią i zachodnią częścią byłej Rusi Kijowskiej. Kształtują się stopniowo dwa ośrodki polityczne roszczące sobie prawo do historycznej spuścizny po Rusi Kijowskiej: Księstwo Halicko-Włodzimierskie na zachodzie i Księstwo Włodzimiersko-Suzdalskie, później zwane Moskiewskim na północnym wschodzie. Księstwo Halickie było powiązane więziami politycznymi, kulturalnymi, a nawet dynastycznymi z Zachodem. Normą były tu koligacje dynastyczne z Polską i innymi krajami Zachodu. Hruszewski zwraca uwagę na liczne związki kulturalne w architekturze, w malarstwie sakralnym, w literaturze kronikarskiej. Autor Kroniki Halicko-Wołyńskiej przytacza na przykład opowieść o św. Kindze nie czyniąc żadnych aluzji, iż była ona świętą „innej wiary”, katoliczką. Katolików zdaję się on traktować jako „chrześcijan”, a zatem ludzi tej samej wiary [Hruszewskyj 1992]. Ruś Moskiewska natomiast zastygła w sztywnej formule bizantyjskiej.

Zachodnie ziemie byłej Rusi Kijowskiej dostają się stopniowo pod panowanie Litwy. W XVI stuleciu cała dzisiejsza Ukraina i Białoruś jest już w składzie Wielkiego Księstwa Litewskiego. W tym ogromnym, wieloetnicznym państwie wyraźnie dominuje kultura „ruska”. Oficjalna nazwa tego państwa brzmiała: „Wielkie Księstwo Litwy, Żmudzi i Rusi”, rządzące elity przyjmowały jednak szybko ruską kulturę, język i obyczaje. Oficjalnym językiem administracji i wymiaru sprawiedliwości była „kancelaryjna ruszczyzna”, mająca w znacznym stopniu elementy żywych wówczas gwar, w szczególności z okolic Wilna. Jednak główny zwód praw Wielkiego Księstwa napisany był językiem Ruskiej Prawdy Jarosława Mądrego. Literatura „wysoka” tego obszaru, która $\mathrm{z}$ istoty miała charakter religijny była pisana w języku cerkiewno-słowiańskim lub jego regionalnych obocznościach. W podobnym języku były pisane kroniki. Procesy kształtowania się tożsamości kulturowej ziem „ruskich” zdynamizowały się pod koniec XVI i w pierwszej połowie XVII stulecia w związku z tworzeniem projektów unii religijnej katolicko-prawosławnej, jej wdrożenia w 1596 roku i jej dalszych losów. Powstaje wówczas bogata literatura polemiczna, prezentująca różne stanowiska wokół kwestii unijnej.

Czołową postacią $\mathrm{w}$ przygotowaniu projektów unijnych po stronie ruskiej był książę Konstanty Ostrogski [zob. przede wszystkim Melnyk 1992]. Po zawarciu Unii stał się jednak głównym jej przeciwnikiem.

Jak stwierdza Wilson, charakter kultury tego obszaru, literatura pisana i jej język nie pozwalają stwierdzić istnienia w owym czasie jakichkolwiek dających się zauważyć różnic między południową jego częścią, zamieszkałą dziś przez Ukraińców, a północną - zamieszkałą przez Białorusinów. Wilson 
pisze: „Przenosząc się z Wilna do Nowogródka czy Kijowa, przedstawiciele tamtejszego kleru i szlachty nie mieli poczucia, że przekraczają wyraźnie zakreślone granice kulturowe" [Wilson 2002: 47].

Zdaniem Wilsona, „dopiero wydarzenia roku 1648 (powstanie Chmielnickiego) i to, co po nich nastąpiło, przesądziły o ostatecznym skrystalizowaniu się różnic między zalążkami narodów „białoruskiego” i „ukraińskiego" [Wilson 2002].

Znacznie wcześniej jednak proces kształtowania się w granicach Wielkiego Księstwa Litewskiego jednolitego narodu „ruskiego”, innego niż naród rosyjski - przerwany został postanowieniami Unii Lubelskiej z 1569 roku. Cały obszar „ruski” podzielony został między Koronę i Litwę. Dzisiejsze ziemie białoruskie znalazły się w obrębie Litwy, ziemie ukraińskie przeszły do Korony. Do Korony przeszło również województwo podlaskie z dawnymi ruskimi grodami: Drohiczynem i Bielskiem.

\section{Religia w historii Ukrainy}

Tradycyjnie badacze kultury słowiańskiego Wschodu zajmowali się kulturą rosyjską lub - w najlepszym razie - kulturą „ruską”, traktując ją jako całość i nie wyodrębniając Ukrainy ani Białorusi. Dotyczy to - także „ruskiej” duchowości, a w jeszcze bardziej ścisłym sensie - „ruskiego” prawosławia. Nie znajdujemy takiego rozróżnienia u wybitnych filozofów rosyjskich zajmujących się historiozofią Rosji - Sołowiowa, Bierdiajewa, Trubieckiego, czy tym bardziej - Dostojewskiego. Również Sołżenicyn w swych przepowiedniach upadku Związku Radzieckiego i prognozach radził przyszłej Rosji zrezygnować z republik Azji Środkowej, traktował natomiast jako rzecz oczywistą i naturalną, że Rosja, Ukraina i Białoruś tworzyć będą jedno państwo. Słowiańskie narody prawosławne były również dla niego narodami tej samej duchowości. Dziś Sołżenicyn jest zaskoczony i oburzony kulturowym i politycznym „dysydenctwem” Ukrainy.

Wprawdzie historycy kultury widzieli odmienność dróg rozwoju kulturowego Moskwy i „ruskich” ziem Wielkiego Księstwa Litewskiego czy później - Rzeczpospolitej, ziemie te traktowali wszakże jako „ruskie”, nie wyodrębniając kompleksu ukraińskiego [Milukov 1889].

Również G. Fłorowski w swym obszernym studium historii teologii rosyjskiej traktuje prawosławie ukraińskie XVII i XVII wieku jako pewną oboczność teologii rosyjskiej, oboczność silnie skażoną wpływami łacińskimi i wielce podejrzaną co do zgodności z autentyczną tradycją prawosławia [Florovskij 1983]. 
Odrębność duchowa Ukrainy była natomiast mocno podkreślana przez ukraińskich romantyków i nacjonalistów - zwłaszcza Dmytro Doncowa. Wśród współczesnych autorów tego nurtu najbardziej poważaną osobą jest Halina Łozko - pracownik Akademii Nauk Ukrainy, etnograf, a jednocześnie założycielka i przywódczyni jednego z kultów neopogańskich. W swych pracach twierdzi ona, iż Ukraina zawsze pozostawała pogańska, elementy pogańskie przetrwały również w prawosławiu Ukrainy i to jest jego osobliwością [Łozko 1995].

$\mathrm{Na}$ szczególną jednak uwagę zasługują głębokie studia nad historią religii Ukrainy zawarte w monumentalnym dziele M. Hruszewskiego Istoryja Ukrainy-Rusi [Hruszewskyj 1995] i w innych jego pracach [Hruszewskyj 1994]. Osobliwości ukraińskiego prawosławia i życia duchowego Ukrainy w ogóle Hruszewski wyprowadza ze specyfiki jej dziejów politycznych i społecznych, a nie z jakichś przyrodzonych cech ludu ukraińskiego, jak to czynią romantycy i nacjonaliści.

Odrębności ukraińskiego prawosławia były też eksponowane w pracach I. Ohijenki [1993]. Główny nacisk autor ten kładzie na intelektualną wyższość prawosławia ukraińskiego w porównaniu z prawosławiem moskiewskim, jego żywe związki z kulturą Zachodu.

Wiaczesław Łypinśkyj - ukraiński filozof i działacz polityczny - odrębności ukraińskiego prawosławia w stosunku do Rosji określa tak: „Prawosławie Ukrainy, (podobnie, jak i moskiewskie staroobrzędostwo) różni się od upaństwowionego, synodalnego moskiewskiego prawosławia tym, że jest ono duchowo i organizacyjnie bliżej bizantyńskich korzeni, a przez Bizancjum bliżej też do korzeni rzymskich, a poprzez korzenie rzymskie do wyrastającego z nich drzewa katolicyzmu” [Łypinśkyj 1995].

Obecnie problem odrębności prawosławia ukraińskiego od prawosławia rosyjskiego podjął ukraiński religioznawca Oleksander Sagan [1996].

Nie ulega wątpliwości, że ukraińskie prawosławie jest całkiem odrębnym zjawiskiem religijno-kulturowym, odmiennym od prawosławia moskiewskiego, posiadającym swoje osobliwości również w aspekcie prawosławia powszechnego. Ogólnie biorąc, specyfiką prawosławia Ukrainy jest większa obecność w nim elementu łacińskiego - zarówno katolickiego, jak i protestanckiego.

Reformy Piotra Mohyły, które uczyniły z Kijowa najbardziej żywy ośrodek myśli prawosławnej w świecie - jednocześnie oddaliły elity prawosławne Ukrainy od wiary ludu i jego duchowości. W Akademii Mohylańskiej wykładało się wyłącznie po łacinie, traktaty teologiczne teologowie prawosławni piszą wyłącznie po polsku, w czasie powstań kozackich 
duchowieństwo prawosławne staje po stronie Rzeczpospolitej. Paradoksem historii Ukrainy tego okresu jest to, iż jednym z głównych haseł powstania Chmielnickiego była „walka za wiarę”, a w 1651 roku metropolita kijowski Sylwester Kosiw wita jako wyzwolicieli wkraczające do Kijowa wojska Rzeczpospolitej. Szybko też dały o sobie znać sprzeczności klasowe - szlachta i elity prawosławne latynizowały się, lud i kozactwo pozostało wierne tradycyjnej, ludowej, „ruskiej” religijności i tradycyjnym wyobrażeniom o prawosławiu. Znajdowali oni poparcie w niższym, pochodzącym z ludu duchowieństwie. Te „ludowe” elementy zadecydowały o podporządkowaniu prawosławia ukraińskiego Moskwie.

Odrębności prawosławia ukraińskiego w XVI-XVII wieku mają dziś sens wyłącznie ideologiczny: można na nich budować ideę odrębności teologicznej prawosławia ukraińskiego i formułować własne oblicze cerkwi ukraińskiej, inne od cerkwi rosyjskiej. Odrębności te dotyczą sposobu myślenia i teoretyzowania elit intelektualnych Kijowa trzysta lat temu, a nie religijności ludu. W tym przypadku trudno jest znaleźć jakieś cechy różniące religijność prawosławnych Ukraińców od religijności Rosjan. Co więcej - trudno faktycznie znaleźć wspólny mianownik religijności dla całej Ukrainy.

\section{Konkluzje}

Z tego pobieżnego przeglądu historii ziemi ukraińskiej nasuwa się kilka wniosków:

1. Już w średniowieczu na obszarze dzisiejszej Ukrainy ścierały się wpływy Zachodu i Wschodu, Rzymu i Bizancjum manifestujące się początkowo w odrębności kultu, zwłaszcza - języka kultu, a później w odrębnościach konfesyjnych katolicyzmu i prawosławia. Na Ukrainie, podobnie jak na całej przestrzeni rubieży łacińsko-bizantyjskiej, o późniejszych dynamizmach procesów etnicznych decydowała nie pierwotna struktura plemienna tych ziem, ale granice oddziaływania chrześcijaństwa wschodniego.

2. W okresie Rusi Kijowskiej na obszarze tego rozległego państwa ukształtowało się poczucie wspólnoty „ruskiej” rozumianej przede wszystkim jako wspólnota wyznawców wschodniego chrześcijaństwa. Resztki wspólnoty „ludu ruskiego” trwały długo po upadku Rusi Kijowskiej. W jakimś sensie jej rudymenty odnaleźć można jeszcze dziś. 
3. W okresie Wielkiego Księstwa Litewskiego kształtuje się świadomość „ruskiego narodu” odrębnego od narodu rosyjskiego w Księstwie Moskiewskim - w aspekcie politycznym, ideologicznym, ale też w znacznym stopniu w sensie religijnym, kulturowym i językowym. Nie daje się natomiast do końca XVI stulecia zaobserwować na tym obszarze odrębnych etnosów - ukraińskiego i białoruskiego. Etnos rusiński stanowił całość odrębną od etosu rosyjskiego.

4. Dyferencjacja na etnos ukraiński i białoruski rozpoczyna się po Unii Lubelskiej, w wyniku której ziemie ukraińskie włączone zostają do Korony, a ziemie białoruskie pozostają przy Litwie. Odrębność polityczną i kulturową ziem ukraińskich pogłębia powstanie Chmielnickiego i wydarzenia, które po nim nastąpiły.

5. Mimo ważkich przeobrażeń politycznych $\mathrm{w}$ ostatnim stuleciu nadal żywa jest konfrontacja cywilizacyjna Zachodu i Wschodu, będących sukcesorami Rzymu i Bizancjum. Ukraina jest polem walki tych cywilizacji zaciekle broniących swych ideologicznych i politycznych uzurpacji. O pokoju na Ukrainie i jakimś politycznym ładzie nie ma dziś co marzyć. Kultywowane namiętnie nastroje konfrontacyjne wśród politycznych i ideologicznych przywódców świata wyryły głęboką „bruzdę” w społeczeństwie Ukrainy. Będzie ona trwać przez dziesięciolecia, jak niezagojona rana. $\mathrm{Na}$ długo pozostanie ból po poniesionych stratach, zabitych i zaginionych. Będą o tym stale przypominać groby bohaterów i męczenników, rocznice bitew i klęsk. Pamięć dramatu zadomowiona zostanie na długo w tradycji rodzinnej, rodzice i dziadkowie będą opowiadać dzieciom i wnukom o okrucieństwach wojny domowej, pokazywać zdjęcia i pamiątki, przynosić kwiaty na groby bohaterów i męczenników, modlić się za ich dusze. Ból i pamięć podsycana będzie przez przebiegłych polityków i ideologów prześcigających się w konfrontacyjnym radykalizmie, odnajdujących w tym swe polityczne powołanie, i drogę do kariery, podsycających bojowe nastroje społeczne.

Prawdziwy pokój na Ukrainie można zatem prorokować za jakichś sto lat, kiedy w zaświaty odejdą rodzice, dziadkowie i wychowawcy młodych pokoleń, a politycy i ideolodzy stonują swój bojowy impet i wystraszą się widma totalnej konfrontacji między Zachodem i Wschodem. 


\section{Bibliografia}

Florovskij G. (1983), Puti russkago bogoslovia, Paris.

Gumilow L. (1997), Drevniaja Ruś i Vielikaja stiep, t. 1, Moskwa.

Hruszewskyj M. (1992), Istorija Ukraini-Rusi, Kyjiv.

Hruszewskyj M. (1994), Duchovna Ukraina, Kyjiv.

Hruszewskyj M. (1995), Istoryja Ukraini-Rusi, t. 1-8, Kyjiv.

Jermałowicz M. (1990), Starażytnaja Biełaruś. Połacki i nowaharodski pieryjad, Minsk.

Łozko H. (1994), Ukrainśkie jazycznictwo, Kyjiv.

Łozko H. (1995), Ukrainśke narodoznavstvo, Kyjiv.

Łypynśkyj W. (1995), Relihija i cerkwa w istorii Ukrajini, Kyjiv.

Melnyk M. (1992), Spór o zbawienie. Zagadnienia soteriologiczne w świetle prawosławnych projektów unijnych, Kraków.

Milukov P. (1889), Oczerki po istorii russkoj kultury, Sant-Peterburg.

Ohyjenko I. (1993), Ukrainśka Cerkwa, Kyjiv.

Paszkiewicz H. (1996), Początki Rusi, Kraków.

Sagan O. (1996), Ukrains'ke pravoslav '/: istoriosofske osmislenne fenomeenu, „Ukrains'ke Religieznavstvi. Bleteen", nr 1, Kiiv.

Wilson A. (2002), Ukraińcy, tłum. Marek Urbański, Warszawa.

Zaharulski E. (1998), Zachodniaja Ruś IX-XII st., Minsk.

\section{SUMMARY}

\section{Complicated fate of Ukraine}

It was already in the Middle Ages that the lands of today's Ukraine were the area of clashes between the East and the West, Rome and the Byzantine Empire. Those clashes were manifested in confessional discrepancies of Catholicism and Orthodoxy as well as the differences in sacral language. In Ukraine, similarly to the whole area of the Latin Byzantine borderline, the decisive factor in the later ethnical processes was not the original tribal structure of those lands, but the scope of the Eastern Christianity influence.

In the days of Kievan Rus', the vast area of this country was home to the general attitude of "Russian" community, primarily understood as the community of Eastern Christianity followers. The remains of the "Russian peoples" community lasted long after the fall of Kievan Rus'. To some extent, its origins can be found until this day.

In the era of the Grand Duchy of Lithuania, emerges the identity of the "Russian nation", separate from the Russians in the Grand Duchy of Moscow in the political, ideological, but also largely in the religious, cultural, and linguistic sense. However, it is not possible to observe separate Ukrainian and Belarussian ethnic groups in this area until the end of the 
XVI century. The Ruthenian ethnos was entirely separate from the Russian ethnos.

The differentiation into the Ukrainian and Belarussian ethnos begins after the Union of Lublin, following which the Ukrainian lands become a part of the Crown, and the Belarussian lands remain a part of Lithuania. The political and cultural independence of Ukrainian lands is consolidated with the Khmelnytsky Uprising and the events that followed.

KEYWORDS: ethnos, civilizational borderland, national identity, religious identity, Catholicism and Orthodoxy 